\title{
GAMBARAN PENGETAHUAN KADER KESEHATAN MENGENAI GIZI IBU HAMIL
}

\section{KNOWLEDGE OF HEALTH CADRE ON NUTRITION OF PREGNANT WOMEN}

\author{
Ratih Indraswari ${ }^{1)}$, Aditya Kusumawati ${ }^{2}$ \\ ${ }^{1,2}$ Bagian Pendidikan Kesehatan dan Ilmu Perilaku \\ Fakultas Kesehatan Masyarakat Universitas Diponegoro Semarang \\ Jl. Prof. Soedarto, SH, Tembalang, Semarang 50275 \\ Email : ratih@undip.ac.id
}

\begin{abstract}
Maternal Mortality Rate (MMR) is still a serious concern of the government. Various efforts have been made to reduce the number in all regions in Indonesia. Village health cadres have an important role in delivering health information and monitoring the health of pregnant women. Maternal health problems are often caused by maternal feeding behaviors that are incompatible with the Balanced Nutrition Guidelines. This study aimed to find out the knowledge of cadres about nutrition of pregnant women. The research method used cross-sectional with quantitative approach and total population sample technique. The sample in this research is 30 health cadres in Pucakwangi Village, Pati Regency, Central Java. The results showed that most cadres knew the definition of nutrition as a substance contained in food (80\%). As many as 50\% of respondents knew the nutritional function for growth, 10\% of cadres did not know that exclusive breastfeeding is only for infants aged 0-6 months, 23.3\% did not know about the provision of Fe tablets to pregnant women. Only $33.3 \%$ of cadres knew that carbohydrates and minerals are nutrients. In addition, only $80 \%$ of cadres knew that basic food needs to be consumed daily. Less than half of cadres who know that milk (26.7\%) and nuts (30\%) are a source of protein. Knowledge of health cadres on the nutrition of pregnant women still needs to be improved, especially regarding the source of nutrition in food and the provision of Fe tablets.
\end{abstract}

Keywords: knowledge, nutrition, pregnant women, cadre.

Abstrak: Angka Kematian Ibu (AKI) masih menjadi perhatian serius pemerintah. Berbagai upaya telah dilakukan untuk menekan tingginya AKI di seluruh wilayah di Indonesia. Kader kesehatan di tingkat desa memiliki peran penting dalam menyampaikan informasi kesehatan dan memantau kesehatan ibu hamil. Masalah kesehatan ibu seringkali disebabkan oleh perilaku makan ibu yang tidak sesuai dengan Pedoman Gizi Seimbang. Penelitian ini bertujuan untuk mencari tahu gambaran pengetahuan kader mengenai gizi ibu hamil. Metode penelitian menggunakan metode cross-sectional dengan pendekatan kuantitatif dan teknik sampel total populasi. Sampel dalam penelitian ini adalah 30 kader kesehatan di Desa Pucakwangi Kabupaten Pati Jawa Tengah. Hasil penelitian menunjukkan bahwa sebagian besar kader mengetahui pengertian gizi sebagai zat yang terkandung dalam makanan (80\%). Sebanyak 50\% responden mengetahui fungsi gizi untuk pertumbuhan, $10 \%$ kader tidak tahu bahwa ASI eksklusif adalah pemberian ASI saja untuk bayi usia 0-6 bulan, 23,3\% tidak tahu mengenai pemberian tablet Fe kepada ibu hamil. Hanya 33,3\% kader yang mengetahui bahwa karbohidrat dan mineral merupakan zat gizi. Selain itu, hanya $80 \%$ kader yang mengetahui bahwa makanan pokok perlu dikonsumsi setiap hari. Kurang dari separuh kader yang mengetahui bahwa susu (26,7\%) dan kacang-kacangan (30\%) merupakan sumber protein. Pengetahuan kader kesehatan mengenai gizi ibu hamil masih perlu ditingkatkan, khususnya mengenai sumber gizi dalam makanan dan pemberian tablet $\mathrm{Fe}$. 
Kata Kunci: pengetahuan, gizi, ibu hamil, kader.

\section{PENDAHULUAN}

Angka Kematian Ibu (AKI) masih menjadi angka yang prestisius di dunia. Status kesehatan suatu negara dapat diukur dengan melihat AKI di masingmasing negara. Semakin rendah AKI suatu negara, maka negara tersebut dianggap mampu menyejahterakan masyarakatnya.

Pemerintah sedang mengupayakan pencapaian Sustainable Development Goals (SDGs) dimana didalamnya terdapat indikator kesehatan berupa penurunan AKI. Hingga tahun 2030, diharapkan terjadi penurunan AKI menjadi 70 per 100 ribu kelahiran hidup.

Penurunan AKI di Indonesia terjadi sejak tahun 1991 sampai dengan 2007, yaitu dari 390 menjadi 228. Namun demikian, SDKI tahun 2012 menunjukkan peningkatan AKI yang signifikan yaitu menjadi 359 kematian ibu per 100.000 kelahiran hidup. AKI kembali menujukkan penurunan menjadi 305 kematian ibu per 100.000 kelahiran hidup berdasarkan hasil Survei Penduduk Antar Sensus (SUPAS) 2015 (Kementerian Kesehatan Republik Indonesia, 2016).

AKI di Provinsi Jawa Tengah cukup disoroti karena pada tahun 2015 terdapat 619 kasus. Tahun 2015 mengalami penurunan signifikan dibandingkan jumlah kasus kematian ibu pada tahun 2014 yang mencapai 711 kasus. Dengan demikian, AKI di Provinsi Jawa Tengah juga mengalami penurunan dari 126,55 per 100.000 kelahiran hidup pada tahun 2014 menjadi 111,16 per 100.000 kelahiran hidup pada tahun 2015. (Dinas Kesehatan Provinsi Jawa Tengah, 2015)

Kabupaten Pati terletak di perbatasan Jawa Tengah dan Jawa Timur. AKI di kabupaten ini cukup tinggi, yakni sebesar 20 kasus pada tahun 2016. Di tahun 2017, Desa Pucakwangi Pati mengalami 5 kasus gizi buruk dan terdapat 20 orang ibu hamil yang mengalami KEK. Di Desa Pucakwangi sendiri bahkan ditemukan 1 kasus AKI dengan riwayat kehamilan ketiga, kelahiran pertama dan pernah satu kali keguguran.

Penyebab kematian Ibu di Provinsi Jawa Tengah yang paling sering adalah karena hipertensi $(26,44 \%)$, perdarahan $(22,93 \%)$, gangguan sistem peredaran darah $(4,64 \%)$ dan infeksi $(3,66 \%)$. Sebesar $57,95 \%$ kematian maternal terjadi pada waktu nifas, pada waktu hamil sebesar 27,00\% dan pada waktu persalinan sebesar $15,05 \%$. Sementara berdasarkan kelompok umur, kejadian kematian maternal terbanyak adalah pada usia produktif (20-34 tahun) sebesar $62,02 \%$, kemudian pada kelompok umur $>35$ tahun sebesar $30,52 \%$ dan pada kelompok umur $<20$ tahun sebesar 7,45\% (Dinas Kesehatan Provinsi Jawa Tengah, 2015).

Tingginya angka kematian ibu menunjukkan keadaan sosial ekonomi yang rendah dan fasilitas pelayanan kesehatan yang rendah pula. Selain itu, perilaku ibu hamil juga mempengaruhi tingginya AKI. Perilaku selama kehamilan pada ibu hamil dipengaruhi oleh beberapa faktor antara lain lokasi demografi ibu hamil yang jauh dari pelayanan kesehatan, penghasilan keluarga yang mempengaruhi perencanaan persalinan, keadaan sosial ekonomi ibu hamil, pendidikan ibu hamil dan pasangan yang mempengaruhi pengetahuan seputar kehamilan dan persalinan, stress selama kehamilan yang berpengaruh pada depresi pada masa kehamilan, jumlah anak dan KB yang diikuti serta pola makan ibu hamil selama kehamilan.

Salah satu masalah gizi yang dialami ibu hamil adalah anemia gizi. Sebagian besar anemia gizi ini adalah anemia gizi besi. Anemia gizi besi ditunjukan dengan kadar hemoglobin seseorang yang berada di bawah batas normal. Prevalensi anemia pada kehamilan secara umum adalah 55\%, dan anemia ini tinggi di usia kehamilan tujuh hingga sembilan bulan. Pada tahun 2001, Departemen Kesehatan Republik Indonesia melalui Survei Kesehatan Rumah Tangga (SKRT) menyebutkan bahwa prevalensi anemia pada ibu hamil 
adalah sebesar $40.1 \%$, pada wanita usia subur 15-44 tahun $27.9 \%$ dan pada balita 48.1\%. Departemen Kesehatan Republik Indonesia tahun 2005 juga menunjukkan bahwa terdapat ibu hamil sebanyak 4 juta per tahun, 2 juta diantaranya mengalami anemia gizi dan 1 juta mengalami KEK (Kekurangan Energi Kronis). Selain itu, berdasarkan data Riset Kesehatan Dasar (2007) menunjukkan bahwa prevalensi anemia pada ibu hamil di Indonesia sebesar 59\% (Kementerian Kesehatan Republik Indonesia, 2016).

Kader kesehatan merupakan ujung tombak sekaligus kepanjangan tangan dari pemerintah dalam mengupayakan peningkatan kesehatan di masyarakat. Kader sangat berperan dalam menyukseskan pembangunan nasional di bidang kesehatan, dimana prinsip dari pelayanan kesehatan menunjukkan bahwa masyarakat itu bukan objek akan tetapi masyarakat adalah subjek dari suatu pembangunan nasional. Kader dianggap sebagai sosok yang paling memahami kondisi kebutuhan akan kesehatan di wilayahnya. Oleh karena itu, seorang kader seharusnya memiliki pemahaman yang benar terkait kesehatan masyarakat.

Peran kader yang sangat krusial tersebut perlu diimbangi dengan pengetahuan yang baik pula mengenai gizi seimbang, khususnya pada ibu hamil. Informasi yang benar yang diterima oleh ibu hamil dari kader dapat membantu dalam upaya peningkatan kesehatan ibu dan anak melalui pencegahan anemia, KEK, dan permasalahan gizi buruk lainnya.

Penelitian ini bertujuan untuk mengetahui gambaran pengetahuan para kader kesehatan mengenai gizi ibu hamil di Desa Pucakwangi Kabupaten Pati. Dengan mengetahui gambaran pengetahuan gizi oleh kader, maka dapat direncanakan solusi masalah KIA yang dapat mendukung upaya penyelamatan Seribu Hari Pertama Kehidupan.

\section{METODE}

Penelitian ini menggunakan metode pendekatan Cross sectional. Pada studi Cross sectional, maka tidak dilakukan tindak lanjut pada objek penelitian.
Metode ini membuat pengukuran dilaksanakan dalam satu waktu atau satu kali saja secara bersamaan. (Soekidjo Notoatmodjo, 2010) Penelitian ini adalah penelitian kuantitatif dengan jenis penelitian adalah penelitian survei (survey research method). Rancangan pada penelitian ini adalah penelitian deskriptif.

Dalam penelitian ini, sampel merupakan ibu kader di Desa Pucakwangi Kabupaten Pati Jawa Tengah sejumlah 30 kader yang berasal dari 6 Dukuh. Teknik sampel yang digunakan adalah teknik total populasi.

Data primer diperoleh dari hasil pertanyaan angket terhadap responden dengan bantuan kuesioner terstruktur. Sedangkan data sekunder diperoleh dari data Dinas Kesehatan, data on line, referensi buku dan jurnal-jurnal ilmiah.

Data yang diperoleh dari jawaban responden akan dianalisis secara kuantitatif, yang dimaksudkan untuk mengolah data dan mengorganisasikan serta mengolah hasil yang dapat diinterpretasikan. Analisis kuantitatif akan dilakukan dengan metode yang telah ditentukan. Analisis univariat, dimana analisis akan menghasilkan distribusi dari tiap variabel, adalah analisis yang digunakan dalam penelitian ini.

\section{HASIL DAN PEMBAHASAN}

Desa Pucakwangi terletak di Kecamatan Pucakwangi, Kabupaten Pati, Jawa Tengah. Kecamatan Pucakwangi sendiri terletak di sebelah tenggara Kabupaten Pati. Dahulunya kecamatan ini menjadi bagian dari Kawedanan Jakenan.

Seluruh responden merupakan kader kesehatan Desa Pucakwangi yang berjumlah 30 kader. Semuanya merupakan perwakilan dari 6 Dukuh di Desa Pucakwangi, yaitu Dukuh Jatilawang, Dukuh Pucakwangi, Dukuh Balong, Dukuh Gandu, Dukuh Budeng, dan Dukuh Sambirowo. Masing-masing dukuh terdapat 5 kader kesehatan yang berpartisipasi menjadi responden dalam penelitian ini.

Sebagian besar responden berusia dewasa awal (26-35 tahun) sebanyak 50\% dan hanya $20 \%$ responden yang berusia remaja akhir (17-25 tahun). Usia 
merupakan salah satu faktor yang dapat mempengaruhi tingkat pengetahuan seseorang. Semakin bertambah usia maka pengetahuan juga meningkat seiring dengan informasi yang didapatkan dan pengalaman pribadi. Semakin cukup umur, tingkat kemampuan dan kematangan seseorang akan lebih tinggi dalam berpikir dan menerima informasi. Namun, seorang yang berumur lebih tua tidak mutlak memiliki pengetahuan yang lebih tinggi dibandingkan dengan seseorang yang lebih muda. Kematangan berpikir seseorang mempengaruhi seseorang untuk bertindak lebih baik terhadap lingkungannya. Umur juga dapat mempengaruhi kondisi fisik, mental, kemauan kerja, dan tanggung jawab seseorang serta kesadaran untuk menjaga kesehatannya. (Soekidjo Notoatmodjo, 2012)

Tabel 1. Distribusi Karakteristik Responden

\begin{tabular}{lrrr}
\hline No. & Karakteristik Responden & Frekuensi (n) & Persentase (\%) \\
\hline 1. & Usia & 6 & \\
& Remaja Akhir & 15 & $50 \%$ \\
& Dewasa Awal & 9 & $50 \%$ \\
& Dewasa Akhir & & $30 \%$ \\
\hline $2 . \quad$ Tingkat Pendidikan & 4 & $13,3 \%$ \\
& Tidak Sekolah & 11 & $36,7 \%$ \\
& Lulus SD/Sederajat & 3 & $10 \%$ \\
& Lulus SMP/Sederajat & 12 & $40 \%$ \\
\hline Lulus SMA/Sederajat & & $100 \%$ \\
\hline $3 . \quad$ Pekerjaan & 30 & \\
& Tidak Bekerja & &
\end{tabular}

Berdasarkan tingkat pendidikan, masih ada responden yang tidak sekolah $(13,3 \%)$ dan sebagian besar responden memiliki pendidikan tamat SMA/sederajat $(40 \%)$. Seseorang dengan pendidikan yang tinggi akan mudah memahami cara untuk memelihara kesehatannya seperti berolahraga, makan makanan bergizi seimbang, istirahat yang cukup dan mampu mengelola stres. Namun perlu ditekankan bahwa seorang yang berpendidikan rendah tidak berarti mutlak berpengetahuan rendah pula. Latar belakang pendidikan mempengaruhi cara berpikir, tindakan dan pengambilan keputusan seseorang dalam melakukan suatu perbuatan (Soekidjo Notoatmodjo, 2012). Seluruh kader dalam penelitian ini merupakan ibu rumah tangga yang tidak memiliki penghasilan sendiri. Pekerjaan dapat mempengaruhi tingkat pengetahuan seseorang melalui adanya pengalaman atau pengetahuan secara langsung maupun tidak langsung. Selain mempengaruhi tingkat pengetahuan, lingkungan pekerjaan juga mempengaruhi perilaku. Lingkungan pekerjaan tidak hanya mempengaruhi perilaku menjadi positif tetapi juga bisa sebaliknya. Orang yang tidak memiliki pekerjaan, walaupun waktu luang lebih banyak namun tanpa kesadaran tentang pentingnya kesehatan maka cenderung enggan dalam melakukan upaya promosi kesehatan maupun prevensi masalah kesehatan. (Soekidjo Notoatmodjo, 2012).

\section{Pengetahuan Gizi Dasar}

Sebagian besar responden $(80 \%)$ mengetahui bahwa gizi merupakan zat yang terkandung di dalam makanan. Sedangkan pengertian gizi sebagai zat yang dibutuhkan tubuh hanya dijawab oleh $43,3 \%$ responden saja.

Istilah gizi atau nutrisi berarti zat makanan atau bahan makanan. Pengertian lebih luas bahwa gizi diartikan sebagai penggunaan makanan oleh setiap organisme melalui beberapa tahapan yakni pencernaan, absorbsi (penyerapan), transportasi, penyimpanan dan metabolisme hingga keluarnya zat gizi dari tubuh organisme. Proses tersebut dilakukan dengan tujuan untuk bertahan hidup, tumbuh dan membantu fungsi organ tubuh agar dapat berfungsi secara 
normal serta menghasilkan energi (Sigit L, 2012).

Kurang dari separuh responden yang dapat menjawab fungsi zat gizi. Nilai tertinggi adalah 50\% ibu kader dapat menjawab fungsi zat gizi sebagai fungsi pertumbuhan. Zat gizi adalah ikatan kimia yang diperlukan tubuh untuk melakukan fungsinya yaitu menghasilkan energi, membangun, memelihara jaringan serta mengatur proses-proses jaringan. Gizi merupakan bagian penting yang dibutuhkan oleh tubuh guna perkembangan dan pertumbuhan dalam bentuk dan untuk memperoleh energi, agar manusia dapat melaksanakan kegiatan fisiknya sehari-hari (Bening, 2014).

Beberapa zat gizi dapat dibuat oleh tubuh sendiri dan sebagian besar lainnya harus diperoleh dari makanan yang dikonsumsi sehari-hari. Zat gizi yang diperlukan tubuh terdiri dari mineral, vitamin, air, karbohidrat, protein dan lemak. Semuanya penting bagi manusia untuk pertumbuhan dan perkembangan manusia, memelihara proses tubuh dan sebagai penyedia energi untuk melakukan aktivitas sehari-hari. Namun kurang dari $75 \%$ responden penelitian ini saja yang mampu menyebutkan jenis-jenis zat gizi tersebut. Bahkan, karbohidrat yang memiliki fungsi vital sebagai penghasil energi hanya dapat dijawab oleh 33,3\% responden saja. Selain karbohidrat, lemak merupakan sumber energi yang sangat dibutuhkan oleh ibu hamil. Namun, kader kesehatan yang mengetahui bahwa lemak termasuk salah satu zat gizi hanya $26,7 \%$ (Muslihah and, Sri Winarsih, Soemardini, AS Zakaria, 2013).

Sebagian besar responden menjawab nasi sebagai contoh sumber makanan yang mengandung karbohidrat. Selain nasi, responden juga mampu memberikan contoh makanan lain seperti jagung dan umbi-umbian sebagai jenis makanan yang kaya karbohidrat. Nasi putih adalah salah satu jenis makanan pokok yang dikonsumsi oleh mayoritas masyarakat Indonesia dan sekitar 50\% penduduk dunia. Selain nasi putih, dikenal juga nasi merah dan nasi hitam yang lebih tinggi seratnya. Nasi putih yang merupakan makanan pokok mayoritas masyarakat
Indonesia memiliki nutrisi yang komplit seperti protein, lemak dan karbohidrat. Selain itu, nasi juga mengandung serat yang berfungsi untuk melancarkan saluran pencernaan serta vitamin dan mineral. Dalam 100 gram nasi putih terdapat kalori 2\% lemak, 89\% karbohidrat, dan 9\% protein (Muslihah and, Sri Winarsih, Soemardini, AS Zakaria, 2013).

Buah dan sayur merupakan jenis makanan yang kaya serat. Hampir seluruh responden menjawab buah sebagai contoh sumber makanan yang mengandung vitamin. Sebagian besar buah yang sering dikonsumsi masyarakat mengandung vitamin seperti vitamin $\mathrm{A}, \mathrm{B} 1, \mathrm{~B} 2$, dan $\mathrm{C}$. Sedangkan makanan yang mengandung sumber protein dapat ditemui di ikan, telur, susu dan kacang-kacangan. Selain itu, contoh makanan yang mengandung lemak seperti susu, keju dan daging dapat dijawab oleh responden meskipun tidak seluruh responden mampu menjawabnya. Pada dasarnya, seluruh manusia membutuhkan makronutrien dan mikronutrien. Makronutrien adalah zat gizi yang dibutuhkan dalam jumlah besar seperti protein, lemak, dan karbohidrat. Meskipun demikian, konsumsi harus dilakukan secara seimbang karena jika berlebihan justru akan membahayakan tubuh sendiri. Sedangkan mikronutrien adalah zat gizi yang dibutuhkan tubuh dalam jumlah kecil. Mikronutrien meliputi 12 vitamin dan 13 mineral yang dibutuhkan setiap hari. Kekurangan kronis vitamin dan mineral dapat memicu berbagai gangguan kesehatan (Syari et al., 2015).

Sumber makanan yang perlu dikonsumsi seseorang setiap hari adalah makanan pokok, sayuran, buah, lauk pauk, dan air putih. Sebagian besar kader mengerti bahwa makanan pokok seperti nasi, jagung dan umbi-umbian perlu dikonsumsi setiap hari, namun sebagian besar juga tidak mengetahui bahwa sayur, buah, lauk pauk (seperti ikan, daging, olahan kedelai, telur, dan lainnya) serta air putih juga sangat perlu dikonsumsi seseorang setiap harinya. Hal ini cukup mengkhawatirkan karena sumber makanan tersebut memiliki fungsi yang sangat dibutuhkan tubuh. WHO telah menghimbau untuk mengonsumsi 
Tabel 2. Distribusi Pengetahuan Gizi Dasar

\begin{tabular}{|c|c|c|c|c|c|}
\hline No & Pengetahuan & Ya & $\%$ & Tidak & $\%$ \\
\hline \multirow[t]{3}{*}{1} & Pengertian gizi & & & & \\
\hline & a. Zat yang terkadung dalam makanan & 24 & $80 \%$ & 6 & $20 \%$ \\
\hline & b. Zat yang dibutuhkan tubuh & 13 & $43,3 \%$ & 17 & $56,7 \%$ \\
\hline \multirow[t]{5}{*}{2} & Fungsi zat gizi & & & & \\
\hline & a. Penghasil energi/tenaga & 11 & $36,7 \%$ & 19 & $63,3 \%$ \\
\hline & b. Pertumbuhan & 15 & $50 \%$ & 15 & $50 \%$ \\
\hline & c. Pengatur fungsi organ & 7 & $23,3 \%$ & 23 & $76,7 \%$ \\
\hline & d. Perkembangan tubuh & 14 & $46,7 \%$ & 16 & $53,3 \%$ \\
\hline \multirow[t]{6}{*}{3} & Jenis-jenis zat gizi & & & & \\
\hline & a. Karbohidrat & 10 & $33,3 \%$ & 20 & $66,7 \%$ \\
\hline & b. Vitamin & 18 & $60 \%$ & 12 & $40 \%$ \\
\hline & c. Mineral & 10 & $33,3 \%$ & 20 & $66,7 \%$ \\
\hline & d. Protein & 19 & $63,3 \%$ & 11 & $36,7 \%$ \\
\hline & e. Lemak & 8 & $26,7 \%$ & 22 & $73,3 \%$ \\
\hline \multirow[t]{4}{*}{4} & $\begin{array}{l}\text { Contoh sumber makanan yang } \\
\text { mengandung karbohidrat }\end{array}$ & & & & \\
\hline & a. Jagung & 9 & $30 \%$ & 21 & $70 \%$ \\
\hline & b. Nasi & 23 & $76,7 \%$ & 7 & $23,3 \%$ \\
\hline & c. Umbi-umbian & 7 & $23,3 \%$ & 23 & $76,7 \%$ \\
\hline 5 & $\begin{array}{l}\text { Contoh sumber makanan yang } \\
\text { mengandung vitamin adalah buah-buahan }\end{array}$ & 27 & $90 \%$ & 3 & $10 \%$ \\
\hline \multirow[t]{5}{*}{6} & $\begin{array}{l}\text { Contoh sumber makanan yang } \\
\text { mengandung protein }\end{array}$ & & & & \\
\hline & a. Ikan & 13 & $43,3 \%$ & 17 & $56,7 \%$ \\
\hline & b. Telur & 20 & $66,7 \%$ & 10 & $33,3 \%$ \\
\hline & c. Susu & 8 & $26,7 \%$ & 22 & $73,3 \%$ \\
\hline & d. Kacang-kacangan & 9 & $30 \%$ & 21 & $70 \%$ \\
\hline \multirow[t]{4}{*}{7} & $\begin{array}{l}\text { Contoh sumber makanan yang } \\
\text { mengandung lemak }\end{array}$ & & & & \\
\hline & a. Susu & 14 & $46,7 \%$ & 16 & $53,3 \%$ \\
\hline & b. Daging & 16 & $53,3 \%$ & 14 & $46,7 \%$ \\
\hline & c. Keju & 2 & $6,7 \%$ & 28 & $93,3 \%$ \\
\hline \multirow[t]{6}{*}{8} & $\begin{array}{l}\text { Sumber makanan yang perlu dikonsumsi } \\
\text { seseorang tiap hari }\end{array}$ & & & & \\
\hline & a. Makanan pokok & 24 & $80 \%$ & 6 & $20 \%$ \\
\hline & b. Sayuran & 10 & $33,3 \%$ & 20 & $66,7 \%$ \\
\hline & c. Buah & 10 & $33,3 \%$ & 20 & $66,7 \%$ \\
\hline & d. Lauk pauk & 14 & $46,7 \%$ & 16 & $53,3 \%$ \\
\hline & e. Air putih & 10 & $33,3 \%$ & 20 & $66,7 \%$ \\
\hline \multirow[t]{7}{*}{9} & $\begin{array}{l}\text { Porsi sumber makanan yang perlu } \\
\text { dikonsumsi seseorang tiap hari }\end{array}$ & & & & \\
\hline & a. Makanan pokok (3-4 porsi) & 25 & $83,3 \%$ & 5 & $16,7 \%$ \\
\hline & b. Sayuran (3-4 porsi) & 22 & $73,3 \%$ & 8 & $26,7 \%$ \\
\hline & c. Buah $(2-3$ porsi $)$ & 27 & $90 \%$ & 3 & $10 \%$ \\
\hline & d. Lauk pauk (2-4 porsi) & 24 & $80 \%$ & 6 & $20 \%$ \\
\hline & e. Air putih (8 gelas / 1,5-2 L) & 30 & $100 \%$ & 0 & $0 \%$ \\
\hline & f. Minyak, gula, garam sesuai kebutuhan & 6 & $20 \%$ & 14 & $46,7 \%$ \\
\hline
\end{tabular}

berbagai jenis sayur dan buah setiap harinya sebanyak 400 gram per orang per hari, yang terdiri dari 250 gram sayur dan
150 gram buah. Demikian juga bagi orang Indonesia yang mayoritas merupakan ras Melayu Mongoloid, dianjurkan agar dapat 
memenuhi asupan gizi melalui sayuran dan buah-buahan dengan porsi 300-400 gram per orang per hari bagi anak balita dan anak usia sekolah.

Sedangkan bagi remaja dan orang dewasa disarankan mengonsumsi $400-$ 600 gram sayur dan buah. Porsi sayur adalah porsi terbesar dari yang dianjurkan, yakni sekitar dua-pertiga dari jumlah anjuran konsumsi sayuran dan buahbuahan (Kemenkes, 2014).

Sebagian besar kader mengetahui takaran atau porsi sumber makanan yang perlu dikonsumsi seseorang setiap harinya. Berdasarkan Panduan Gizi Seimbang, seseorang dewasa perlu mengonsumsi makanan pokok sebanyak 3-4 porsi, sayuran sebanyak 3-4 porsi, buah 2-3 porsi, dan 2-4 porsi lauk pauk. Kebutuhan tubuh akan air pada tiap orang dipenuhi melalui konsumsi makanan dan minuman. Bagi kelompok remaja dan dewasa dengan kegiatan relatif ringan pada suhu kamar, dibutuhkan setidaknya dua liter atau delapan gelas air setiap harinya. Namun kebutuhan air atau minuman pada ibu ketika hamil dan menyusui perlu ditambahkan dari dua liter kebutuhan dasar akan air. Tambahan kebutuhan tersebut berkisar satu liter air per harinya, sehingga total kebutuhan air pada ibu hamil dan ibu menyusui sebesar tiga liter atau kurang lebih 13 gelas setiap hari. Selain kecukupan jumlah konsumsi air untuk tubuh, perlu diperhatikan juga keamanan dari air yang diminum. Air yang aman berarti air yang dikonsumsi bukanlah air yang mengandung bahan berbahaya dan mengandung kuman, virus dan bakteri yang dapat menimbulkan penyakit. Berbeda dengan konsumsi air, konsumsi gula dan minyak yang melebihi kebutuhan tubuh justru akan berakibat pada peningkatan berat badan. Jika minyak dan gula dikonsumsi terus menerus dalam waktu yang lama, maka hal ini dapat secara langsung membuat kadar gula darah menjadi meningkat. Lebih lanjut hal ini akan memicu terjadinya penyakit-penyakit degeneratif seperti diabetes, kanker dan penyakit jantung. Selain itu, kandungan garam $(\mathrm{NaCl})$ yang menciptakan rasa asin pada makanan perlu diperhatikan juga jumlah dan kebutuhannya. Kebutuhan manusia akan garam sama halnya dengan kebutuhan akan minyak dan gula. Pada dasarnya kebutuhan manusia akan ketiga zat tersebut sangat sedikit bahkan beberapa sumber menyebutkan ketidakbutuhan akan zat tersebut. Namun kebutuhan ini berbeda pada penderitapenderita penyakit tertentu sehingga konsumsinya perlu diperhatikan agar tidak semakin merugikan kesehatan. Konsumsi makanan dengan rasa asin yang berlebihan berakibat pada kenaikan tekanan darah sehingga memicu munculnya penyakit degeneratif lainnya. Itulah alasan mengapa pemakaian garam dalam makanan hanya secukupnya saja atau disesuaikan dengan kebutuhan masing-masing orang (Kemenkes, 2014).

\section{Pengetahuan Gizi Kehamilan}

Sebagian besar kader $(86,7 \%)$ menyatakan bahwa ada pantangan makanan bagi ibu hamil. Makanan yang dihindari dikonsumsi oleh ibu hamil seperti ikan laut, daun pepaya, pare, buah nangka dan buah durian. Hal ini sesuai dengan penelitian lain kepada ibu hamil yang mengalami KEK (Kurang Energi Kronis) yang menyebutkan bahwa makanan yang dipantang adalah makanan yang bergetah seperti buah nangka, pepaya muda, nanas dan durian. Buahbuah tersebut dipercaya akan menimbulkan rasa panas, perut kembung, hingga kontraksi rahim. Kontraksi rahim yang sangat buruk pada trimester pertama kehamilan menjadi ancaman keguguran janin (Oktriyani, Muhammad Juffrie, 2014).

Selain itu, ibu hamil juga menghindari makan ikan lele dan meminum air es. Alasan yang disebutkan beraneka ragam seperti nasehat orang tua atau bidan sehingga harus dipatuhi, agar anak tidak nakal, agar tidak menghambat jalan lahir bayi, dan agar ukuran bayi tidak menjadi terlalu besar sehingga menyebabkan kendala dalam proses kelahiran (Oktriyani, Muhammad Juffrie, 2014).

Anggapan masyarakat mengenai bayi dengan ukuran badan besar pada umumnya adalah bayi yang memiliki berat lahir diatas 3,5 kilogram. Sedangkan secara ilmu kesehatan, bayi dengan 
ukuran berat badan lebih besar dari ukuran normal sehingga memiliki implikasi terhadap kesehatan dan kemampuan bayi untuk bertahan hidup disebut dengan istilah makrosomia. Hal ini berbahaya bagi bayi dan ibu karena merupakan salah satu penyebab morbiditas dan mortalitas pada keduanya. Bayi penderita makrosomia ini mempunyai berat lahir sebesar $\geq 4$ kilogram. Penyebab dari bayi makrosomia bukanlah karena konsumsi air dingin pada ibu semasa kehamilannya, melainkan riwayat Diabetes Melitus (DM) dan obesitas. Kedua penyebab tersebut diakibatkan oleh pola makan si ibu. Upaya pencegahan yang dapat dilakukan

Tabel 3. Distribusi Pengetahuan Gizi Ibu Hamil

\begin{tabular}{|c|c|c|c|c|c|}
\hline No & Pengetahuan & $\mathbf{Y a}$ & $\%$ & Tidak & $\%$ \\
\hline 1 & $\begin{array}{l}\text { Adakah makanan yang perlu dihindari } \\
\text { (tabu) ibu hamil? }\end{array}$ & 26 & $86,7 \%$ & 4 & $13,3 \%$ \\
\hline 2 & $\begin{array}{l}\text { Ibu hamil perlu makan lebih banyak dari } \\
\text { sebelum hamil agar penambahan berat } \\
\text { badan sesuai dengan umur kehamilan. }\end{array}$ & 29 & $96,7 \%$ & 1 & $3,3 \%$ \\
\hline 3 & $\begin{array}{l}\text { Bagi ibu hamil yang terlalu gemuk, kurangi } \\
\text { porsi makanan sumber energi dari lemak } \\
\text { dan karbohidrat. }\end{array}$ & 29 & $96,7 \%$ & 1 & $3,3 \%$ \\
\hline 4 & $\begin{array}{l}\text { Bila ibu hamil terlalu kurus, tambahkan } \\
\text { porsi makanan sumber energi dan protein. }\end{array}$ & 29 & $96,7 \%$ & 1 & $3,3 \%$ \\
\hline 5 & $\begin{array}{l}\text { Ibu hamil sebaiknya mengonsumsi } \\
\text { makanan dengan porsi kecil tapi sering. }\end{array}$ & 22 & $73,3 \%$ & 8 & $26,7 \%$ \\
\hline 6 & $\begin{array}{l}\text { Untuk menghindari penimbunan } \\
\text { cairan/edema, ibu hamil perlu } \\
\text { memperhatikan penggunaan garam dalam } \\
\text { makanan dan minuman agar tidak } \\
\text { berlebihan. }\end{array}$ & 25 & $83,3 \%$ & 5 & $16,7 \%$ \\
\hline 7 & $\begin{array}{l}\text { Ibu hamil perlu mengonsumsi tablet } \\
\text { tambah darah selama masa kehamilan. }\end{array}$ & 26 & $86,7 \%$ & 4 & $13,3 \%$ \\
\hline 8 & $\begin{array}{l}\text { Ibu hamil perlu mengonsumsi tablet } \\
\text { tambah darah setidaknya } 90 \text { tablet selama } \\
\text { masa kehamilan. }\end{array}$ & 23 & $76,7 \%$ & 7 & $23,3 \%$ \\
\hline 9 & $\begin{array}{l}\text { Ibu hamil perlu mengonsumsi makanan } \\
\text { bergizi seimbang. }\end{array}$ & 29 & $96,7 \%$ & 1 & $3,3 \%$ \\
\hline 10 & $\begin{array}{l}\text { Ibu hamil perlu meningkatkan porsi } \\
\text { makannya } 2 \text { kali lipat dari sebelum hamil. }\end{array}$ & 21 & $70 \%$ & 9 & $30 \%$ \\
\hline 11 & $\begin{array}{l}\text { Bayi usia } 0-6 \text { bulan dianjurkan } \\
\text { mengonsumsi ASI saja }\end{array}$ & 29 & $96,7 \%$ & 1 & $3,3 \%$ \\
\hline 12 & $\begin{array}{l}\text { Bayi usia 6-9 bulan dianjurkan } \\
\text { mengonsumsi ASI dan makanan lumat } \\
\text { (saring halus) }\end{array}$ & 29 & $96,7 \%$ & 1 & $3,3 \%$ \\
\hline 13 & $\begin{array}{l}\text { Bayi usia } 9-12 \text { bulan dianjurkan } \\
\text { mengonsumsi ASI dan makanan lembik } \\
\text { (saring kasar) }\end{array}$ & 29 & $96,7 \%$ & 1 & $3,3 \%$ \\
\hline 14 & $\begin{array}{l}\text { Bayi usia } 12-24 \text { bulan dianjurkan } \\
\text { mengonsumsi ASI dan makanan keluarga }\end{array}$ & 29 & $96,7 \%$ & 1 & $3,3 \%$ \\
\hline 15 & $\begin{array}{l}\text { ASI eksklusif adalah konsumsi ASI saja } \\
\text { tanpa penambahan zat lain. }\end{array}$ & 27 & $90 \%$ & 3 & $10 \%$ \\
\hline
\end{tabular}

adalah dengan memperbaiki pola makan pada remaja putri agar sesuai dengan panduan gizi seimbang. Itulah kenapa jumlah dan jenis makanan perlu diatur 
agar tidak mengakibatkan bahaya kesehatan dalam jangka pendek maupun jangka panjang. Dalam pedoman gizi seimbang telah disarankan untuk mengurangi konsumsi gula dan minyak serta memperbanyak asupan sayur dan buah (Beigi et al., 2013; Merita, 2015; Melani, 2016).

Hampir seluruh kader mengetahui bahwa ibu hamil perlu makan dengan porsi lebih banyak dari sebelum hamil untuk menambah berat badan $(96,7 \%)$. Selain itu, ibu hamil juga harus lebih sering makan $(73,3 \%)$ daripada jarang makan namun dalam porsi besar sekaligus. Frekuensi makan sangat berkaitan dengan pemenuhan kebutuhan zat gizi yang dibutuhkan oleh tubuh. Pola makan yang dianjurkan bagi ibu hamil yaitu porsi makan yang kecil tapi sering minimal lima kali sehari. Jumlah atau porsi makan yang dikonsumsi seseorang mempengaruhi zat gizi yang masuk ke dalam tubuh. Frekuensi makan merupakan seringnya seseorang melakukan kegiatan makan dalam 1 hari, baik makanan utama maupun makanan pendamping atau selingan. Dalam sehari, seseorang makan utama sebanyak tiga kali dan memakan makanan selingan sebanyak dua kali. Namun untuk ibu hamil, kebutuhan gizi per harinya disesuaikan dengan usia kehamilannya. Hal ini dikarenakan adanya perkembangna dan pertumbuhan janin. Pada trimester pertama, seorang ibu hamil membutuhkan tambahan energi sebanyak $180 \mathrm{Kkal}, 20$ gram protein, 6 gram lemak dan 25 gram karbohidrat. Dengan demikian, kebutuhan gizi per hari seorang ibu hamil dapat disetarakan dengan sebuah biskuit ukuran besar, sebuah telur ayam rebus, dan setengah gelas susu sapi segar. Sedangkan pada trimester 2 dan 3, ibu hamil membutuhkan tambahan $300 \mathrm{Kkal}, 20$ gram protein, 10 gram lemak, dan 40 gram karbohidrat. Jumlah tersebut setara dengan sebutir telur ayam rebus dan semangkuk bubur kacang hijau yang terdiri dari 5 sendok makan kacang hijau, seperempat gelas santan dan 1 sendok makan gula merah (Kemenkes, 2014; Oktriyani, Muhammad Juffrie, 2014).

Ibu hamil harus mengurangi lemak dan karbohidrat jika sudah terlalu gemuk (96,7\%). Kegemukan dapat menjadi factor penyulit ketika proses kelahiran bayi. Selain itu, makan berlebih juga menyebabkan diabetes dan preeklamsia yang berbahaya bagi ibu dan janinnya. Preeklamsia muncul pada ibu hamil setelah usia kehamilan 20 minggu atau segera setelah persalinan. Hingga sekarang penyebab eklamsia dan preeklamsia belum diketahui secara pasti. Namun, gejala yang menegakkan kondisi tersebut diantaranya adalah penambahan berat badan secara berlebih, edema, hipertensi dan proteinuria. Peningkatan berat badan sekitar 1 kilogram per minggu dan terjadi selama beberapa kali merupakan tanda dari penambahan berat badan yang berlebihan. Sedangkan edema seringkali terlihat sebagai peningkatan berat badan dan juga karena adanya pembengkakan pada jari tangan, kaki dan muka. Sedangkan hipertensi pada ibu hamil adalah jika tekanan darah $\geq 140 / 90$ $\mathrm{mmHg}$ atau tekanan sistolik meningkat > $30 \mathrm{mmHg}$ atau tekanan diastolik > 15 $\mathrm{mmHg}$ yang diukur setelah ibu hamil beristirahat selama 30 menit. Jika tekanan diastolik pada kehamilan trimester kedua lebih dari $85 \mathrm{mmHg}$ maka dapat dicurigai sebagai potensi preeklamsia (Radjamuda, 2014).

Selain itu, kegemukan dapat mengakibatkan suplai nutrisi ke janin menjadi terhambat karena pembuluh darah ibu menjadi sempit. Jika tidak segera ditangani, maka keadaan ini dapat mengakibatkan kematian janin di dalam rahim. Oleh sebab itu, berat badan ibu hamil sangat penting untuk terus dimonitoring agar tidak mengakibatkan dampak yang buruk baik bagi ibu maupun bayinya.

Hampir seluruh responden menyatakan bahwa ibu hamil perlu menambah sumber protein dan energi jika terlalu kurus (96,7\%). Selain itu, konsumsi garam perlu lebih diperhatikan untuk mencegah edema pada janin yang dikandung oleh ibu hamil. Nutrisi yang seimbang merupakan hal yang penting diperhatikan ibu hamil. Melalui pola makan yang tepat, ibu hamil dapat memenuhi kebutuhan nutrisi bagi tumbuh kembang janin maupun bagi kesehatan ibu. Pola makan dapat memperlihatkan 
macam makanan dan seberapa banyak bahan makanan yang dimakan seseorang setiap hari. Pola makan juga menunjukkan kekhususan suatu kelompok masyarakat tertentu. Berdasarkan Panduan Gizi Seimbang tahun 2014, karbohidrat, protein, dan lemak merupakan zat gizi makro yang sangat dibutuhkan ibu hamil. Sebagian besar kader di Desa Pucakwangi telah mengetahui bahwa ibu hamil perlu mengonsumsi makanan dengan gizi seimbang, dimana sumber energi diperoleh melalui konsumsi nasi. Hal ini sesuai dengan penelitian pola makan terhadap ibu hamil yang lain dimana beras menjadi sumber karbohidrat utama yang paling sering dikonsumsi ibu selama hamil. Beras termasuk makanan pokok di Indonesia yang sering dikonsumsi dan diproduksi hingga diekspor keluar negeri. Lebih dari setengah penduduk dunia juga mengonsumsi beras sebagai makanan pokok. Konsumsi beras masyarakat Indonesia cukup tinggi yaitu sebesar $139,5 \mathrm{~kg}$ per tahunnya (Bezaliel $\mathrm{R}$ Narasiang, Nelly Mayulu, 2016) (Kemenkes, 2014).

Tidak semua kader mengetahui bahwa ibu hamil perlu mengonsumsi tablet Fe setidaknya 90 tablet selama masa kehamilannya. Padahal, zat besi merupakan salah satu zat gizi yang sangat dibutuhkan oleh ibu hamil. Bahkan sebelum hamil, perempuan direkomendasikan untuk mencukupi kebutuhan zat besinya. Zat besi diperlukan untuk membuat hemoglobin, yaitu sebuah protein dalam sel darah merah yang membawa oksigen ke seluruh sel dalam tubuh. Selain itu, zat besi juga bertindak sebagai senyawa penting dalam mioglobin, yaitu protein yang membantu menyediakan oksigen pada otot dan dalam pembentukan kolagen. Kekurangan zat besi dapat menyebabkan anemia defisiensi besi yang berbahaya untuk ibu hamil. Anemia defisiensi besi merupakan penyebab utama tingginya Angka Kematian Ibu di Indonesia. Ibu hamil dengan anemia sangat berisiko mengalami komplikasi selama kehamilan, proses kelahiran bayinya, maupun saat nifas. Anemia dapat membuat sistem kekebalan tubuh ibu menjadi lemah, sehingga ibu mudah terkena penyakit infeksi. Selain berisiko pada ibu, anemia defisiensi besi juga dapat menimbulkan risiko pada bayi karena dapat menyebabkan kelahiran prematur, berat badan lahir rendah, dan kematian bayi (Simanjuntak and Sudaryati, 2011).

Pengetahuan hampir seluruh kader kesehatan di Desa Pucakwangi mengenai cara pemberian makan pada bayi umur 0-24 bulan sudah baik. Kader mengerti bahwa bayi yang berumur kurang dari 24 minggu harus mengonsumsi ASI Eksklusif. Meskipun demikian, hanya 90\% yang mengerti bahwa ASI Eksklusif memiliki pengertian yaitu pemberian ASI saja pada bayi usia 0 hingga 6 bulan pertama kehidupan. Setelah 6 bulan, bayi diperbolehkan untuk mendapatkan makanan pendamping. Meskipun demikian, pemberian ASI Eksklusif tetap harus dilanjutkan hingga anak berusia 24 bulan.

Tiap kader kesehatan seharusnya telah memahami seluk beluk ASI Eksklusif sehingga mampu membantu warganya yang sedang mengalami permasalahan mengenai pemberian ASI Eksklusif kepada bayinya. Beberapa alasan yang sering terjadi pada ibu-ibu yang gagal memberikan ASI Eksklusif pada bayinya antara lain: air susu tidak keluar atau keluar namun jumlahnya sangat tidak mencukupi kebutuhan bayi, ibu kurang memahami penatalaksanaan dalam pemberian ASI dengan benar, misalnya pentingnya pemberian ASI pada bayi, fisiologi menyusui mengenai bagaimana cara ASI dapat dikeluarkan, posisi menyusi yang baik dan pelekatan antara ibu dan bayi saat menyusui sehingga bayi dapat menghisap air susu dengan efektif dan air susu dapat keluar dengan optimal. Selain itu, cara pemberian ASI bila ibu tidak dapat memberikan secara langsung kepada bayinya, misal karena pekerjaan atau hal lain yang mengharuskan bayi berpisah dengan ibunya (Turlina and Wijayanti, 2015).

Keberhasilan ASI Eksklusif sangat dipengaruhi oleh dukungan dari lingkungan sekitar termasuk pemerintah. Petugas kesehatan dan kader kesehatan perlu memfokuskan pencapaian pemberian ASI Eksklusif karena hal ini 
berpengaruh terhadap kesehatan bayi kelak hingga dewasa. Jumlah dan jenis makanan yang dikonsumsi ibu menyusui memang tidak secara langsung mempengaruhi kualitas dan jumlah air susu yang dihasilkan. Nutrisi yang terkandung dalam 1 liter ASI setara dengan unsur nutrisi yang terdapat dalam 2 piring nasi dan 1 butir telur sehingga diperlukan makanan tambahan untuk ibu yang sedang menyusui (Turlina and Wijayanti, 2015).

Kampanye ASI Eksklusif telah lama digalakkan karena ASI memiliki manfaat terbaik untuk ibu dan bayinya, diantaranya adalah mudah dicerna oleh bayi. ASI sangat mudah dicerna oleh bayi usia 0-6 bulan karena pencernaan bayi di bawah 6 bulan belum sempurna. ASI juga mengandung antibodi alami bagi tubuh bayi agar dapat mencegah terinfeksi penyakit. ASI merupakan makanan yang paling tepat untuk bayi usia 0-6 bulan dengan suhu dan volume yang sesuai. (Kemenkes RI, 2015)

\section{SIMPULAN}

Masih ada kader kesehatan yang tidak tahu mengenai pentingnya tablet $\mathrm{Fe}$ untuk ibu hamil. Kader juga tidak banyak yang mengerti mengenai sumber atau jenis makanan yang mengandung zat gizi tertentu. Selain itu, kader yang belum mengetahui pengertian ASI eksklusif juga masih perlu menjadi sorotan. Pengetahuan kader kesehatan mengenai gizi ibu hamil di Desa Pucakwangi Pati masih perlu ditingkatkan, khususnya mengenai sumber gizi dalam makanan dan pemberian tablet Fe.

\section{DAFTAR PUSTAKA}

Beigi, M. et al. (2013) 'Fetal Macrosomia: Risk Factors, Maternal, and Perinatal Outcome', Annals of Medical and Health Sciences Research, 3(4).

Bening, S. (2014) 'Perbedaan Pengetahuan Gizi, Body Image, Asupan Energi Dan Status Gizi Pada Mahasiswi Gizi Dan Non Gizi Universitas Diponegoro', jurnal undip, 1(11), p. 5.
Bezaliel R Narasiang, Nelly Mayulu, S. K. (2016) 'Gambaran Pola Konsumsi Makanan pada Ibu Hamil di Kota Manado', Jurnal e-Biomedik, 4.

Dinas Kesehatan Provinsi Jawa Tengah (2015) 'Profil Kesehatan Provinsi Jawa Tengah', Dinas Kesehatan Provinsi Jawa Tengah, pp. 48-49. Available at: dinkesjatengprov.go.id/v2015/dokumen/pr ofil2015/Profil_2015_fix.pdf.

Kemenkes (2014) 'Pedoman Gizi Seimbang', Riskesdas, p. 99.

Kemenkes RI (2015) 'Dukung Ibu Bekerja Beri Asi Eksklusif', Kementerian Kesehatan Republik Indonesia, pp. 15-16. Available at: http://www.depkes.go.id/article/print/150 91400003/dukung-ibu-bekerja-beri-asieksklusif.html.

Kementerian Kesehatan Republik Indonesia (2016) Profil Kesehatan Indonesia, Profil Kesehatan Provinsi Bali.

L, S. (2012) 'Keadaan Status Gizi Terhadap Pertumbuhan dan Perkembangan Anak', Lumbung Pustaka UNY, pp. 10-40.

Melani, A. (2016) Faktor-faktor Risiko yang Mempengaruhi Kelahiran Makrosomia. Semarang.

Merita (2015) 'Faktor Resiko Bayi Lahir Gemuk (Makrosomia) di Indonesia', Jurnal Akademika Baiturrahim, 4(2), pp. 1-10.

Muslihah, N. and , Sri Winarsih , Soemardini , AS Zakaria, Z. (2013) 'Kualitas Diet Dan Hubungannya Dengan Pengetahuan Gizi , Status Sosial Ekonomi , Dan Status Gizi', Jurnal Gizi dan Pangan, Maret 2013, 8(1): 71-76, 8(1), pp. 71-76.

Oktriyani, Muhammad Juffrie, D. A. (2014) 'Pola Makan dan Pantangan Makan Tidak Berhubungan dengan Kekurangan Energi Kronis pada Ibu Hamil', Jurnal Gizi dan Diettetik 
Indonesia, 2, pp. 159-169.

Radjamuda, N. (2014) 'Faktor-Faktor Risiko Yang Berhubungan Dengan Kejadian Hipertensi Pada Ibu Hamil Di Poli Klinik Obs-Gin Rumah Sakit Jiwa', Jurnal Ilmiah Bidan, 2(1), pp. 33-40.

Simanjuntak, D. H. and Sudaryati, E. (2011) Gizi pada Ibu Hamil dan Menyusui, Universitas Sumatera Utara.

Soekidjo Notoatmodjo (2010) Metodologi Penelitian Kesehatan. Jakarta: Rineka Cipta

Soekidjo Notoatmodjo (2012) Pendidikan
Kesehatan dan Ilmu Perilaku. Jakarta: Rineka Cipta.

Syari, M. et al. (2015) 'Peran Asupan Zat Gizi Makronutrien Ibu Hamil terhadap Berat Badan Lahir Bayi di Kota Padang', Jurnal Kesehatan Andalas, 4(3), pp. 729737.

Turlina, L. and Wijayanti, R. (2015) 'Pengaruh Pemberian Serbuk Daun Pepaya terhadap Kelancaran ASI pada Ibu Nifas di BPM Ny. Hanik Dasiyem, Amd.Keb di Kedungpring Kabupaten Lamongan', Surya, 07 No.01. 